\title{
The role of atmospheric-tropospheric rivers in partitioning coastal habitats and limiting the poleward expansion of mangroves along the southeast coast of Brazil
}

\begin{abstract}
Atmospheric tropospheric rivers (ARs) in South America are critically important to agriculture, power generation, and the overall economic growth of countries linked by fluvial networks. These moisture conveyor belts in South America are linked to the recently recognized South American Monsoon System (SAMS) which is a distinctive feature of the continent's climate and frequently associated with extreme events such as severe convection, precipitation and damaging floods. They are critical component of the planetary hydrologic cycle, water balance and surface hydrology. One of the most distinctive features of the South America's continent hydrology are ARs which are part of the SAMS which we suggest plays a key role in regulating the extent and development of coastal systems such as mangroves and salt marshes near their southern limit along the coast of Brazil. We suggest that an aerial branch of the SAM's atmospheric system is responsible to a great degree for the observed discrete and sharply defined limit of mangroves and salt marsh at Laguna (28 $30^{\circ}$ 'S), Santa Catarina state. The sharp terminus on the southern Brazilian coast is considered anomalous and has attracted the attention of various researchers who have posited diverse hypotheses to explain the apparent anomaly. Climate is generally recognized to be among the first order controls of mangrove development along with geomorphology and ocean currents. Temperature is an important factor defining the mangrove-salt marsh spatial configuration. Mangroves are mostly tropical species and do not tolerate frost. It has been speculated that climate change could increase temperatures and favor the southwards expansion of mangroves as well as encroachment on salt marshes. In Brazil, the presence of a northerly flowing longshore current has been suggested as a critical factor limiting the southward dispersal in to what appears to be suitable barrier lagoon habitat. We suggest that a combination of interacting factors actually limits southward expansion:
\end{abstract}

a. A coastal geomorphology that creates a bottleneck narrowing the coastal plain;

b. A microtidal regime (tides $<1 \mathrm{~m}$ ) coupled with a high wave energy and sediment transport regime that chokes inlets; and

c. An intense precipitation from a branch of the SAM's that acts as an AR which favors strong limnification of the choked Patos-Mirim lagoon system.

Moisture-flux transport by a Low-Level Jet that runs along the subtropical plains, at about $25^{\circ} \mathrm{S}$ to $30^{\circ} \mathrm{S}$, feeds deep convection, high precipitation and water surpluses at the South America's east coast. This results in the widespread freshening of the PatosMirim lagoonal hydrologic system that extends along the southerly Brazilian coast from $30^{\circ} 30^{\prime} \mathrm{S}$ to Chui $33^{\circ} 45^{\prime} 07^{\prime} \mathrm{S}$, at the border with Uruguay.

Keywords: south american monsoon system, atmospheric rivers, austral limits for the atlantic's south american mangroves and salt marshes
Volume 3 Issue 2 - 2019

\author{
Gilberto Cintrón-Molero,' Yara Schaeffer- \\ Novelli $i^{1,2,3}$ \\ 'Instituto BiomaBrasil, Recife, Brazil \\ ${ }^{2}$ Department of Biological Oceanography, Instituto \\ Oceanográfico, University of São Paulo, São Paulo, Brazil \\ ${ }^{3}$ IUCN SSC Mangrove Specialist Group, Brazil
}

\begin{abstract}
Correspondence: Yara Schaeffer-Novelli, Department of Biological Oceanography, Oceanographic Institute, University of São Paulo, Praça do Oceanográfico, I9I, 05508- I20, Cidade Universitária, São Paulo, SP, Brazil,Tel +55 I I 9-9997-8402, Email novelliy@usp.br
\end{abstract}

Received: August 15, 2018 | Published: March II, 2019

\section{Introduction}

Atmospheric tropospheric rivers (ARs) in South America are critically important to agriculture, power generation, and the overall economic growth of countries linked by fluvial networks. ARs act as moisture conveyor belts that are linked to the recently recognized South American Monsoon System (SAMS) which is a distinctive feature of the continent's climate and is now regarded as one of the most important of the world's monsoon phenomena. ${ }^{1}$ The SAMS encompasses half of the continent's air shed. Although frequently associated with extreme events such as severe convection, precipitation and damaging floods ARs are critical component of the planetary hydrologic cycle, water balance and surface hydrology. Atmospheric rivers are not an emergent or new phenomenon, they are narrow moisture corridors; aerial branches of the hydrologic cycle that transport large amounts of moisture. ARs were first described in the 1990's. ${ }^{2}$ The regional circulation features of the South American continent are described. ${ }^{3}$ Morais-Arraut et al. ${ }^{4}$ related the Amazonian and subtropical rainfall to these atmospheric "rivers" and "lakes". There are two prominent weather-making ARs; the South America Low-Level Jet (SALLJ) and the South Atlantic Convergence Zone (SACZ), as well as the huge "atmospheric lake" fed by the Trade Winds moisture which produces rain over the Amazon Rain Forest. The SAMS is described ${ }^{1}$ and $^{5}$ in comprehensive reviews. The hallmark 
signature of the mature SAM; the SACZ exits the continent near $25^{\circ} \mathrm{S}$ to $30^{\circ} \mathrm{S}$. Associated with the monsoon systems is a Low-Level South America Jet (SALLJ) that flows east of the Andes and veers into the plains reaching the Atlantic influenced by the Chaco Low at about $25^{\circ} \mathrm{S} .{ }^{6}$ Atmospheric moisture flows into the coastal area along a corridor defined by the South America's Chaco-Pampa basin between $28^{\circ} \mathrm{S}$ and $34^{\circ} \mathrm{S}$ and from longitude $058^{\circ} \mathrm{W}$ to $050^{\circ} \mathrm{W}$. This region is also known as the "subtropical plain" and is characterized by its low relief and highlands to the north. ${ }^{6}$ The combination of atmosphericmoisture transport from the SAMS ${ }^{1}$ southward along the low relief of the South America's Chaco-Pampa basin, ${ }^{6}$ by the Low-Level Chaco Jet (LLCJ) creates a moisture corridor along which deep convection and large mesoscale convective systems (MSCS's) develop and move east toward the coast. These systems create extreme convective precipitation, orographic rainfall, and cyclogenesis which combine to produce extreme precipitation events and high annual rainfall averaging 1,200 $\mathrm{mm}$ but exceeding 2,000 $\mathrm{mm}$ during El Niño warm events (ENSO - El Niño Southern Oscillation). ${ }^{7}$ Subtropical South America has the world's deepest convective storms and most robust mesoscale convective systems responsible for climatological extreme events. ${ }^{8}$

\section{Brazil's coastal habitat and the patos-mirim lagoon system}

Along Brazil's coastline, under conditions of moisture deficits $(\mathrm{P}<\mathrm{PET})$ lagoon chocking leads to hypersalinity (salinity $>40$ to 50 ) as high as twice seawater concentration as in Ararauma Lagoon at $22^{\circ} 50^{\prime} \mathrm{S} .^{9}$ However, in the intermediate portion of the coast in southeasterly Brazil between Santos (São Paulo state) and Laguna (Santa Catarina state) well-developed mangrove forests are found. ${ }^{10-12}$ The signature of intense moisture flux is evident in precipitation levels above $1,400 \mathrm{~mm} / \mathrm{yr}$ but tidal amplitudes near 2 meters force seawater inland maintaining salinities between 20 to 30 that are suitable for mangrove and salt marsh development. Mangroves develop in the lagoonal/estuarine systems along the coast south to Laguna $\left(28^{\circ} 30^{\prime} \mathrm{S}\right) \cdot{ }^{13}$ Beyond this point mangrove forests and salt marshes are abruptly replaced by freshwater formations and are absent along the $620 \mathrm{~km}$ microtidal coastal tract characterized by the Patos-Mirim Lagoon System (PMLS). This system has only two inlets, Tramandaí on the north and Patos at its southern end. ${ }^{14}$ Both inlets remain open due to the continuous fresh water discharges. In terms of climate change, palynological studies at Tramandaí Inlet $\left(29^{\circ} 59^{\prime} \mathrm{S}\right.$, at the northern part of the PMLS), shows continuous fluvial influence and constant dominance by fresh water marsh species during the last 5,000 years. ${ }^{15}$ Within this coastal plain there are numerous lakes and ponds, the largest being Patos and Mirim that together occupy an area comparable to Lake Maracaibo in Venezuela, or an area slightly smaller than Lake Ontario in North America. A notable difference on this coast from the rest of the Brazilian littoral is the absence of mangrove and salt marshes.

Laguna (28 30'S), the austral limit for mangroves in the eastern South American continent is an estuary less than $100 \mathrm{~km}$ north of the PMLS hydrologic complex that extends along the coast from $30^{\circ} 30^{\prime}$ 'S to Chui ( $33^{\circ} 45^{\prime} 07^{\prime \prime}$ ) $)$ at the border with Uruguay. The PMLS is a distinctive feature of the coastal barrier system that extends for $620 \mathrm{~km}$ along the entire coast of Rio Grande do Sul. The microtidal regime (tides $<1 \mathrm{~m}$ ) combines with precipitation to maintain an almost permanent oligohaline lagoon environment. The oligohaline character of the PMLS hydrography reflects the degree to which the system is influenced by fluvial and atmospheric inputs and the extreme "chocking" by intense longshore sand transport and reduced tidal forcing to work against a large almost permanent freshwater head. ${ }^{16}$ Although considered as a coastal lagoon Patos-Mirim covers 10,360 $\mathrm{km}^{2}$ and is essentially a system of coastal lakes that receives water from a $200,000 \mathrm{~km}^{2}$ watersheds. ${ }^{17}$ strongly influenced by the South American Monsoon System. Discontinuities in the barrier occur only near Cassino Beach where the Patos Lagoon Inlet is located $\left(32^{\circ} 10^{\prime} \mathrm{S}\right)$, and at Tramandaí Inlet (29 $\left.59^{\prime} \mathrm{S}\right)$. Its estuarine portion is limited to about $10 \%$ of the total area $\left(900 \mathrm{~km}^{2}\right)$, at the southern end next to the system's main inlet. ${ }^{14}$ Atypical wet conditions for a subtropical mid latitude setting and high river discharge maintain the enclosed lagoons as a fresh water system incompatible with mangrove development.

\section{Final considerations}

The austral limit for mangroves in the eastern South America's continent occurs at Laguna (28 30 'S), Santa Catarina state. Although in other parts of the world mangroves are found in more austral settings such as at Tauranga (37 $\left.30^{\circ} \mathrm{S}\right)$ New Zealand, at Westport Bay $\left(38^{\circ} 45^{\prime} \mathrm{S}\right)$ near Melbourne and at Corner Inlet (38 $\left.54^{\prime} \mathrm{S}\right)$, in Australia .${ }^{18}$ The sharp terminus on the Brazilian coast seems anomalous and has attracted the attention of various researchers who have posited diverse hypotheses to explain the apparent anomaly. Climate is generally recognized to be among the first order controls of mangrove development along with geomorphology. Temperature and frost frequency control the latitudinal incursions because mangroves are a tropical system limited to regions where the temperature of the coldest month is above $20^{\circ} \mathrm{C}$, or the sea surface temperature is above $18^{\circ} \mathrm{C}$ and where freezing events are rare.

The PMLS straddles a region where vapor flux converges along a continental scale depression and which exits the continent in its proximity. Mesoscale Convective Complex's (MCC's) are maintained by the presence of unstable inflows, often Low-Level Jets (Low-Level Chaco Jet) ${ }^{19}$ As a result, precipitation in the region is high, ranging from 1,000 to $1,500 \mathrm{~mm} /$ year and explosive cyclogenesis is observed in the continent between $25^{\circ} \mathrm{S}$ to $35^{\circ} \mathrm{S}$. These moisture flows interact synergistically with Polar fronts and with ENSO warm events causing anomalous precipitation extreme conditions in this region as well. ${ }^{20}$ Evaporation is estimated to be in the range of $800-900 \mathrm{~mm} / \mathrm{yrs}$ so that water surpluses provide for runoff and seepage throughout the year.

Finally, we suggest that the relative stability in Tramandaí Inlet within the last 5,000 years ${ }^{15}$ reflects the persistence of the regionalscale monsoon system that distributes moisture within the region and the permanent geographic constraints (the Andean Cordillera) that funnel moisture consistently as well as the constancy of the Atlantic Subtropical-Highs which are the ultimate drivers of moisture into the continent. Furthermore, within climate change events and with temperature as an important factor defining the mangrove-salt marsh spatial configuration, increasing temperatures should favor the southwards expansion of mangroves and encroachment on salt marshes. However, warming is expected to trigger increase convective activity, stronger and more frequent warm ENSO events, and increase blockage of mangrove by fresh water rather than propiciate southward expansion.

\section{Acknowledgment}

The authors acknowledge the team at Intituto BiomaBrasil (IBB), a nonprofit organization concerned with the use of science to ensure social-ecological sustainability. 


\section{Conflict of interest}

The authors declare that they have no conflict of interest.

\section{References}

1. Carvalho LMV, Cavalcanti IFA. The South American Monsoon System (SAMS). In: Carvalho J, Editor. The Monsoons and Climate Change: Observations and Modelling. Springer: NY. 2016;253.

2. Newell RE, Newell NE, Zhu Y, et al. Tropospheric Rivers? A pilot study Geophysical Research Lett. 1992;19:2401-2404.

3. Satyamurty P, Nobre CA, Silva Diaz PL. South America. In: Karoly DJ, Vincent DG. Meteorology of the Southern Hemisphere. American Meteorological Society, Boston Mass. 1998;410.

4. Morais-Arraut J, Nobre C, Barbosa HM, et al. Aerial Rivers and lakes: Looking at large-scale moisture transport and its relation to Amazonia and to subtropical rainfall in South America. AMS $J$ of Climate. 2012;25(2):543-556.

5. Silva VBS, Kousky VE. The South American Monsoon System: Climatology and Variability. In: Shi-Yu Wang, Gillies RR, Editors. Modern Climatology. 2012;123-152.

6. Bridges EM. World Geomorphology. Cambridge University Press. UK. $1990 ; 260$.

7. Salio P, Nicolini M, Zipser EJ. Mesosclae convective systems over Southeastern South America and their relationship with the Sout American low-level jet. Mon Weather Rev. 2007;135:1290-1309.

8. Zipser EJ, Cecil DJ, Liu C, et al. Where are the most intense thunderstorms on Earth. Bulletin American Meteorological Society. 2006;87:1057-1071.

9. Gabaglia FAR. As Fronteiras do Brasil. Reprint 2018. Facsimile Publisher, Delhi, India. 1916;331

10. Hueck K. Los Bosques de Sur América. GTZ. Sociedad Alemaña de Cooperación Técnica. República Federal Alemaña. 1978;476.
11. Lamberti A. Contribuição ao conhecimento da ecologia das plantas do manguezal de Itanhaém. Universidade de São Paulo, Faculdade de Filosofia, Ciencias e Letras Bol. 1969;23:217.

12. Schaeffer-Novelli Y, Cintrón-Molero G, Adaime RR, et al. Variability of Mangroves along the Brazilian Coast. Estuaries. 1990;13(2):204-218.

13. Cintrón G, Schaeffer-Novelli Y. Los manglares de la costa brasileña: Revisión preliminar de la literatura y II. Los manglares de Santa Catarina. Informe Técnico preparado para la Oficina Regional de Ciencia y Tecnología para América Latina y el Caribe - ROSTLAC/ UNESCO y la Universidad Federal de Santa Catarina. Edición y revisión electrónica: Guilherme Moraes de Oliveira Abuchahla. 1981;47.

14. Odebrecht C, Secchi ER, Abreu PC, et al. Biota of the Patos Lagoon estuary and adjacent marine coast: long-term changes induced by natural and human-related factors. Marine Biology Research. 2017;13(1):3-8.

15. Lorscheitter ML, Dillenburg SR. Holocene paleoenvironments of the northern coastal plain of Rio Grande do Sul, Brazil reconstructed from palynology of Tramandai lagoon sediment. In: Rebassa J \& Salemme M, Editors. Quaternary of South America and Antarctica Penninsula. AA Balkema, Rotterdam Brookfield. 1998;73-97.

16. Kjerfve B. Comparative oceanography of coastal lagoons. In: Wolfe DA, Editors. Estuarine Variability. New York, Academic Press. 1986;63-81.

17. Odebrecht $\mathrm{C}$, Abreu PC, Bemvenuti CE, et al. The Patos Lagoon Estuary, Southern Brazil: Biotic responses to natural and anthropogenic impacts in the last decades (1979-2008). In: Kennish MJ and Paerl HW, Editors. Coastal Lagoons: Critical Habitats of Environmental Change. CRC Press Boca Raton. 2010;558.

18. ARC - Auckland Regional Council. New Zealand mangroves. Auckland, New Zealand. 2007.

19. Markowski P, Richardson Y. Mesoscale Meteorology in Midlatitudes. Willey-Blackwell, UK. 2016;407.

20. Garreaud RD, Aceituno P. Atmospheric Circulation and Climate Variability. In: Veblem TT, et al. Editors. Physical Geography of South America. Oxford, UK. 2007;361. 